\title{
IAMJ
}

INTERNATIONAL

AYURVEDIC

MEDICAL JOURNAL

\section{AN OVERVIEW ON YOGA ALONGSIDE ITS BENEFITS IN MENARCHE AND MENOPAUSE}

\author{
Kshama Kulkarni $^{1}$, Tejashwini Hiremath ${ }^{2}$, Shreyas Swamidas ${ }^{3}$, I.B. Kotturshetti ${ }^{4}$ \\ ${ }^{1}$ PG Scholar, Department of PG Studies in Prasuti Tantra and Stri Roga, Rajiv Gandhi Education Society's \\ Ayurvedic Medical College Hospital \& PG Research Centre, Ron, Karnataka, India \\ ${ }^{2}$ Assistant professor, Department of Samhita and Siddhanta, DGM Ayurvedic Medical College Hospital and \\ Research Centre, Gadag. Karnataka, India \\ ${ }^{3}$ Associate Professor, Department of Prasuti Tantra and Stri Roga, Rajiv Gandhi Education Society's Ayurvedic \\ Medical College Hospital \& PG Research Centre, Ron, Karnataka, India \\ ${ }^{4}$ Principal, CMO and Sr Professor, Rajiv Gandhi Education Society's Ayurvedic Medical College Hospital \& PG \\ Research Centre, Ron, Karnataka, India
}

Corresponding Author: kshama.san26@gmail.com

\section{https://doi.org/10.46607/iamj4709092021}

(Published Online: September 2021)

Open Access

(C) International Ayurvedic Medical Journal, India 2021

Article Received: 29/08//2021 - Peer Reviewed: 06/09/2021 - Accepted for Publication: 07/09/2021

\section{Check for updates}

\section{ABSTRACT}

Menarche and Menopause are two important milestones of a women's life. Menarche is the first menstrual period and menopause is the complete cessation of the menstrual cycle. These milestones are universal and show a mark of the beginning and end of a woman's reproductive phase. From menarche to menopause, a woman's body undergoes a lot of physical, physiological, and psychological transformations. This physical and mental health can be restored through noninvasive methods i.e. Yoga. Yoga plays the role of a healer for a new set of physical and mental changes in women. The most common Yoga practices are Asana (postures), Pranayama (breath regulation) and Dhyana (meditation). Therefore, Yoga has been considered as a therapeutic tool to achieve positive health and to cure diseases. The exact mechanism of how yoga helps in various disorders is not known. There may be neuro-hormonal pathways with a selective effect in each pathological situation. The integrated ap- 
proach of Yoga is effective in managing the healthy menstruation and menopausal symptoms and overall health of women.

Keywords: Menstruation, Menopause, Yoga, Pranayama

\section{INTRODUCTION}

Since in the last few years, Yoga appears to be everywhere, good for everything and suitable for everyone. Yoga is an ancient Indian art designed to bring the balance and health to the physical, mental, emotional and spiritual spheres of an individual ${ }^{1}$. Most commonly Yoga is misunderstood as a form of physical exercise. But there is a vast difference between Yoga and other physical exercises. Yogasana is psychophysiological, whereas physical exercises are purely external. Yoga is a culture to the body, the mind and soul, and is practised with deeper awareness, bringing equipoise of body and mind. But physical exercise is mainly emphasized for body movements.

The history of Yoga goes way beyond 2500 years. The word "Yoga" comes from a Sanskrit root "Yuj" which means union or yoke, to join, and to direct and concentrate one's attention ${ }^{2,3}$. Patanjali Muni, the founder of Yoga, described the practice of Yoga of Ashtanga (eight limbs) as a practical way to evolve the mind, body and soul, they are Yama, Niyama, Asana, Pranayama, Pratyahara, Dharana, Dhyana, Samadhi, but the most commonly performed Yoga practices are Asana (postures), Pranayama (controlled breathing) and Dhyana (meditation) ${ }^{4}$. The main goal of Yoga is to calm the mind, to provide better coordination of mind and body. So that healthy life can be achieved with spiritual growth.

Pranayama is a Sanskrit word meaning "restraint of the Prana or breath", commonly known as breath control. The practice of Pranayama develops a steady mind, strong willpower and better judgment. It strengthens the lungs, improves their function and enhances lung power. It improves the defence mechanism of the body, slows down mental chatter, and infuses positive thinking.
Dhyana (Meditation) is a process whereby consciousness looks in and acts upon itself. The aim of Dhyana is to help the mind and to practice some form of contemplation or introspection ${ }^{5}$.

A woman who is trying to live a successful life as per the expectations and norms of society today it is continually challenged with rapidly accumulating stresses. She must keep perfect health and harmony to withstand the stress and strains of life. The menstrual cycle is a key indicator of overall health for all women of reproductive age. Yoga provides great help at puberty when the body is changing to womanhood. Yogasana and Pranayama as part of her way of life will be even more meaningful and advantageous to her.

Therefore, Yoga has been utilized as a therapeutic tool to achieve total positive health and as a curative measure for various diseases. The exact mechanism as to how Yoga helps in various disease conditions is not known. It has been suggested that there might be neuro-hormonal pathways with a selective effect in each pathological situation. Yogasana may bring about a normalization of the pathological state by control of counter-regulatory hormones or by increased receptor sites. It has also been suggested that Yogic practices create a hypothermic state and an alteration in the sympathetic-parasympathetic axis ${ }^{6}$. Thus, Yoga features great potency to yield physical and psychological states, which is essential for women.

\section{MENSTRUATION PHASE:}

Adolescence is that the transition period of growth from childhood to maturity. The first stage of womanhood is menarche. Menarche is the first menstrual period. During this phase, physical and mental changes occur.

Menstruation is defined as the visible manifestation of cyclic physiologic uterine bleeding due to 
shedding of the endometrium, following invisible interplay of hormones mainly through the Hypothalamo-pituitary-ovarian axis ${ }^{7}$. It starts at about 12 years and ends between 45 and 55 years. The period of the menstrual cycle is a time of cleansing and reflection for the woman. It is a purely physiological process preparing the female body for reproduction. Regarding the menstrual cycle, all women are different and there are no set of rules to practice during menstruation but there are some general guidelines that can be adopted.
During this period listening to one's own body is important.

\section{YOGA DURING MENSTRUAL CYCLE:}

During the cycle initial 2-3 days (48 to 72 hours) a rest is advised, at this time Yoga practice is done to align the body with the frequency of the earth, to gather energy, and to rest. This is the most sensitive part of the cycle, but to a certain point, the normal practice of Asana and Pranayama can be done and certain practices should be avoided.

Table 1: List of Asanas during menstruation ${ }^{8}$

\begin{tabular}{|l|ll|}
\hline \multicolumn{1}{|c|}{ Yogasana } & \multicolumn{2}{c|}{ Benefits } \\
\hline $\begin{array}{l}\text { Utthita Trikonasana (Tri- } \\
\text { angle pose) }\end{array}$ & - & Helps to relieve low back pain. \\
\hline $\begin{array}{l}\text { Uttanasana (Standing for- } \\
\text { ward bend) }\end{array}$ & - & Reduce cramping, excessive bleeding and bloating. \\
\hline $\begin{array}{l}\text { Janu Sirsasana with legs } \\
\text { apart (Head to Knee Pose) }\end{array}$ & - & Provide relief from low backache, headache, menstrual cramps and migraine \\
\hline $\begin{array}{l}\text { Supta virasana } \\
\text { (Reclining Hero Pose) }\end{array}$ & - & $\begin{array}{l}\text { Reduce pelvic pain and abdominal cramps. } \\
\text { It helps to get rid of fatigue. }\end{array}$ \\
\hline
\end{tabular}

\section{A) Pranayama(Breath regulation):}

Pranayama is very useful during menstruation, as it helps to balance emotions and calm the mind. It can also help to relieve pain. Deep breathing is very beneficial, especially when practiced in Tadagasana (Pond Pose) or Shavasan (Corpse Pose).

Practice of:

- Viloma Pranayama I and II

- Bhramari (Humming Bee Breath),

- Anulom viloma (Alternate Nostril Breathing),

- Ujjayi (Victorious Breath)

- Sheetali (Cooling breath through the tongue)

- Sitkari (Cooling breath through the teeth).

\section{B) Dhyana(Meditation):}

Dhyana is the most beneficial practice. Particularly, chanting 'OM' Kar and meditating on 'Om' can be used. Antar mouna, the practice of inner silence is a technique where one observes one's own thoughts. Chanting of Mahamrityunjaya mantra will give benefits as of simple meditation on the breath or ajapa japa. Currently Yoga nidra (yogic sleep) is also highly recommended.

\section{Yogasana's to be avoided during menstrual phase':}

1. Inversion Asanas like Sirasana, Halasana, etc. are avoided throughout menstruation. Because inversion Yogasana disturbs Apana vayu, it is one among panchavayu which normally flows in the downward direction from the manipura chakra (naval centre) to mooladhar chakra (cervix), is reversed. This helps to awaken the Kundalini but during menstruation, it goes against the natural flow. Thereby it disturbs the menstrual cycle causing reproductive issues. In an another view, during inversion asanas the uterus is pulled towards the head and causes the broad ligaments to be overstretched causing a partial collapse of the veins, leaving open arteries to continue pumping blood. This can cause 
vascular congestion and increased menstrual bleeding

2. Very strong vinyasa like Urdhva Prasarita Padasana, Ustrasana, Dhanurasana, Dvi Pada Vipartta Dandasan etc., strong backbends, twists, arm balances and standing positions that put a lot of stress on the abdomen and pelvic region are to be avoided. At these positions, there is a need for more physical strength and exertion that is lacking during this period.

3. Deep Pranayama: Bhastrika (Bellow's Breath), Suryabedan (Right Nostril Breathing) and $\mathrm{Ka}$ palbhati (Frontal Brain Cleansing), fast breathing, strain with the breath, and practice of Kumbakha is avoided because it will increase the heat and redirect the Prana Vayu in the upward direction, that will increase the body heat which may cause heavy bleeding and exerts excessive pressure on the abdominal region.

4. Bandhas should be avoided. While considering on a pranic level, they move the Apana Vayu upwards instead of down and physically they add more contraction to an already tight region and in the case of Uddiyan bandha increasing the heat of the body causing heavy bleeding

\section{YOGA AFTER THE MENSTRUATION:}

After the menstruation period one must begin with the following Asanas and Pranayama to help the organs to recover from menstruation, balance of hor- mones levels, re-establish a balanced mental state and prepare the body for the next cycle.

- Adho Mukha Svanasana (Downward Dog Pose)

- Pascimottanasana (Seated forward bend)

- Supta Baddha Konasana (Reclining butterfly pose)

- Sarvangasana Setu-bandha (Bridge posture)

- Ujjayi Pranayama I and II (Ocean breath)

- Anuloma Viloma Pranayama I and II(Alternative nostril breathing)

- Surya Bhedana Pranayama (Right nostril breathing)

Menstrual Disorders ${ }^{10}$ : The pressure of living up to expectations adds to the stress of a hectic schedule. This stress, along with other aspects of modern life, such as a change in food habits, lack of physical exercise can contribute to the breakdown of the immune system and disturbances of the hormonal system.

Menstrual disorders are common in women of the reproductive age group. A menstrual disorder is a physical or emotional issue interfering with the normal menstrual cycle, causing pain, excessive bleeding, delayed cycle, delayed menarche and missed periods. Several diseases related to menstruation respond well to the practice of Yoga. Regular and proper practice of Asanas and Pranayama are beneficial to treat menstrual disorders.

Table 2: List of Asanas in menstrual disorder

\begin{tabular}{|l|l|}
\hline MENSTRUAL DISORDER & ASANAS \\
\hline Amenorrhea & $\begin{array}{l}\text { Pindasana in Sirsasana (Headstand pose), } \\
\text { Halasana } \text { (Plough pose) } \\
\text { Bhujangasana } \text { (Cobra pose) }\end{array}$ \\
\hline Dysmenorrhea & $\begin{array}{l}\text { Baddha konasana } \text { (Bound angle pose) } \\
\text { Virasana } \text { cycle (Hero Pose) } \\
\text { Supta Virasana } \text { (Reclining hero pose) }\end{array}$ \\
\hline Menorrhagia & $\begin{array}{l}\text { Uttanasana } \text { (Standing forward bend) } \\
\text { Pascimottanasana } \text { (Seated forward bend) } \\
\text { Kurmasana } \text { (Turtle pose) }\end{array}$ \\
\hline Metrorrhagia & $\begin{array}{l}\text { Dandasana } \text { (Staff pose) } \\
\text { Malasana } \text { (Squat pose) }\end{array}$ \\
& $\begin{array}{l}\text { Salamba Sirsasana } \text { (Headstand pose) } \\
\text { Hypomenorrhoea }\end{array}$ \\
\hline Vrksasana (Tree pose)
\end{tabular}




\begin{tabular}{|l|l|}
\hline & $\begin{array}{l}\text { Utthita Trikonasana } \text { (Triangle pose) } \\
\text { Ardha Candrasana } \text { (Half-moon pose) }\end{array}$ \\
\hline Oligomenorrhoea & $\begin{array}{l}\text { Salamba Sarvangasana } \text { (Supported shoulder stand) } \\
\text { Karnapidasana (Ear pressure pose) } \\
\text { Ustrasana (Camel Pose) }\end{array}$ \\
\hline Polymenorrhoea & $\begin{array}{l}\text { Janu Sirsasana } \text { (Head-to-knee pose) } \\
\text { Maricyasana } \text { I (Sage pose) } \\
\text { Siddhasana (Accomplished pose) }\end{array}$ \\
\hline Premenstrual tension & $\begin{array}{l}\text { Matsyasana } \text { (Fish pose) } \\
\text { Maha Mudra } \\
\text { Viloma Pranayama I and II }\end{array}$ \\
\hline
\end{tabular}

\section{MENOPAUSE}

Just as menarche, menopause is another physiological state in the life of a woman. Menopause is a natural phenomenon and a point in life that all women experience. Menopause is defined as the permanent cessation of menstruation that occurs at a mean age of 50 years ${ }^{11}$. A woman spends almost one-third of her life in this phase ${ }^{12}$. This phase shows the end of natural fertility in a woman.

Around $20 \%$ of the patients suffer from severe menopausal symptoms, $60 \%$ of patients suffer from mild symptoms and $20 \%$ of patients may have no symptoms at all ${ }^{13}$. During perimenopause, there are fluctuating estrogen and progesterone levels that manifest in uncomfortable psychological, somatic and vasomotor symptoms. The most common menopausal symptoms include hot flashes, night sweats, fatigue, pain, tiredness, insomnia, and weight gain, lack of concentration, urinary frequency, vaginal dryness, decreased libido and mood swings. These symptoms vary in severity and character from person to person.

As estrogen deficiency is the main cause of perimenopausal symptoms, Hormonal replacement therapy (HRT) is the most effective treatment. But HRT is associated with an increased risk of breast cancer, uterine cancer, thromboembolic heart disease and stroke. Today more women are becoming aware of the serious side effects of HRT; hence the use of HRT for menopausal symptoms has been decreased. Considering the limitations of contemporary treatment i.e., HRT, Yoga can be adopted as complementary therapy ${ }^{14,15}$. Yoga is a non-hormonal, nonpharmacological way of managing menopause.
The following Asanas provide a soothing sensation to the nerves:

- Prasarita Padottanasana (Wide Stance Forward Bend)

- Adho Mukha Svanasana (Downward Dog Pose)

- Pascimottanasana (Seated Forward Bend Pose)

- Salamba Sirsasana (Supported Headstand pose)

\section{Benefits of Yoga during menopause:}

The practice of Yoga on regular basis helps to reduce the effects of menopausal symptoms. But a Yoga practice cannot directly affect an estrogen production. Hatha yoga, restorative postures can help to calm the nervous system by turning down the sympathetic nervous system (fight or flight response) and supporting activation of the parasympathetic nervous system (relaxation response), as well as enhances the functioning of the endocrine system thereby supporting the body in adapting to hormonal fluctuations.

With menopause, the risk of CVD rises commonly due to the co-incident increase in insulin resistance and related atherogenic changes together comprise the metabolic or insulin resistance syndrome, a cluster of metabolic and hemodynamic abnormalities strongly implicated in the pathogenesis and progression of $\mathrm{CVD}^{16}$. There is evidence suggesting the practice of Yoga can decrease both psychological and physiological risk factors for CVD and may reduce signs, complications and improve the prognosis of those with clinical or underlying disease ${ }^{17,18}$

Pranayama (Breath regulation): Pranayama strengthens mental concentration, induces relaxation. Psychological stress is a general trigger of hot flushes. Practices with relaxation and deep abdominal 
breathing are effective for mitigating mild to moderate hot flushes ${ }^{19}$. Also, it is known that the meditation techniques in Yoga bring about a clear change in perception, attention and cognition ${ }^{20}$. Yoga showed an improvement in cognitive function ${ }^{21}$. Practice of: $U j$ jayi Pranayama I, Viloma Pranayama, Surya Bhedana Pranayama are beneficial.

Dhyana (Meditation): Dhyana aims at mental clarity. Increases plasma melatonin levels and melatonin effectively improves sleep quality. Studies have demonstrated the effectiveness of Yoga in improving sleeping patterns suggests its effective use in a clinical setting to combat symptoms of insomnia and other sleep disorders in postmenopausal women ${ }^{22}$. Hence Yoga as an alternative therapy is safe, free from untoward effects, could be a choice for reducing menopausal symptoms and promoting quality of life.

\section{DISCUSSION}

As said, no knowledge is gained instantly. Knowledge features a beginning but without stopping. This is all true with Yoga. One's progress in this field depends entirely on one's inner strength and endurance. Yoga aim is to develop symmetry, coordination, and endurance in the body. It activates the internal organs and makes them function harmoniously. The progress is slow but certain. None can deny the advances of modern medical science. Even though drugs and medicines are often of great help, but Yoga can complement them and speed up the method of recovery, where medication is getting used. Sometimes drugs and medicines have harmful side effects and Yoga helps to counteract them. Yoga strengthens the body's natural defences to fight disease.

From the onset of puberty to menopause, a woman's body endures in a lot of physical and mental strain. Hence the practice of Yoga on daily basis promotes overall health to women. Yoga offers innumerable benefits to women like improving the reproductive system, helping in natural childbirth, giving complete workout to the body.

Healthy menstruation indicates a healthy state of the body. During this period body undergoes a lot of changes physiologically and psychologically. Due to lifestyle modifications, there is a breakdown of the immune system and alter in the hormonal system causing various conditions like fibroid tumours, endometriosis, ovarian cyst, menstrual disorders. Here Yoga plays a vital role. Yoga reduces psychological conditions like stress, tension, depression, and anxiety.

Menopause is the period of wisdom for the woman. This is a critical period of adjustment. Menstruation either stops suddenly or becomes irregular, or the quantity lessens. All these are natural signs that the reproductive functions are coming to an end. At the beginning of menstruation, physical, physiological, and psychological disturbances occur; and women again must face disturbances at the stage of menopause too. Yoga promotes positive psychophysiological changes in post-menopausal women and can be applied as a complementary therapy. At this point, the practice of Yoga Asana, Pranayama are extremely beneficial, as it calms the nervous system and brings equipoise.

\section{CONCLUSION}

Adolescence age is a perfect time to begin the practice of Yoga. It will not only help to develop a healthy and regular menstrual cycle but will also help to deal with various psychological changes. Yoga is highly effective and is strongly recommended to all women. It brings about an overall transformation in one's physical, mental, and moral well-being. Yoga practice, however is very personal, so each Asana is individualized upon one's own body. Hence Yoga as an alternative therapy is safe, free from untoward effects, and could be a best choice for women, from menarche to menopause and promoting quality of life. Yogasana and Pranayama as part of her way of life will be even more meaningful and advantageous to her. Hence it is never too late to begin. Yoga supports a woman throughout all the phases of her life.

\section{REFERENCES}

1. Alyson Ross and Sue Thomas. (2010). The health benefits of yoga and exercise. A review of comparison 
studies. The Journal of Alternative and complementary medicine vol. 16, number 1, Pg. 3-12

2. Lasater J. (1997). The heart of Patanjali. Yoga J. 137:134-44. [Google Scholar]

3. Raub JA. (2002). Psychophysiological effects of Hatha yoga on musculoskeletal and cardiopulmonary function: A literature review. J Altern Complement Med. 8:797-812.

4. Vaze N, Joshi S (2010). Yoga and the menopausal transition. J Midlife Health 1: 56-58.

5. Stevens P. (2010). What is meditation? J Yoga Ontogenet Andtherap Investig; 2:16

6. Sahay BK. (1995). Yoga is medicine. API textbook of medicine. 5th ed. Pg.no. 1444-1445

7. D.C. Dutta, Textbook of Gynecology, fourth edition,Pg.no-.74

8. The women's Yoga Book by Bobby Clennell Pg no. $47-49$

9. https://www.yogapoint.com/yoga-poses/yoga-formenstruation.htm

10. Yoga -a gem for women by Geeta Iyengar on menstrual disorders; Pg.no-97-99

11. Wheln TJ. Goss PE, Ingle JN, Pater JL TUDS, Pritchard K et.al. Assessment of quality of life, In M.A.17: A Randomized placebo-controlled Trial. J Clin Oncol.2005; 23: 6931-40 Pub Med.www.ncbi.nlm.nih.gov)

12. US Census Bureau 1996 Global ageing into the 21st century. The wall chart by the US.

13. Turnbull S. Yoga as a treatment for menopausal symptoms. J Yoga Ontogenet Andtherap Investing 2010; 2:14-5

14. Cohen L, Wameke C. (2004) Psychological Adjustment and sleep quality: A randomized trial of the effects of a Tibetan Yoga intervention in patients with lymphoma. Cancer; 100: 2253-60.

15. Khalsa SB. (2004) Treatment of chronic Insomnia with Yoga: A preliminary study with sleep-wake diaries. Appl Psycho Physio Biofeed Back; 29:269-78

16. A. Risk indices associated with insulin resistance syndrome, cardiovascular disease, and possible protection with yoga: A systematic review. J Am Board Fam Pract 2005;18:491-519

17. Chattha R, Nagarathna R, Padmalatha V, Nagendra HR. (2008). Effect of yoga on cognitive functions in climacteric syndrome: A randomized control study, BJOG 115: 991-100

18. Innes KE, Selfe TK, Taylor AG. Menopause, the metabolic syndrome, and mind-body therapies. Available from:

http://www.ncbi.nlm.nih.gov/pmc/articles/PMC28105 43/, Pg.no-1- 12.

19. Zman LC, Edelberg R, Swart Kemmann E. (1990). Impact of stress on objectively recorded menopausal hot flushes and flush report bias. Health Psychol 9: 529-545

20. Keefer L, Blanchard EB. (2005). Hot flash, hot topic: Conceptualizing menopausal symptoms from a cognitive-behavioral perspective. Appl Psychophysiol Biofeedback 30: 75-82

21. Brown DP. (1977). A model for the levels of concentrative meditation. Int J Clin Exp Hypn 25: 236-273

22. Khalsa SB. Treatment of Chronic Insomnia with Yoga: A preliminary study with sleep-wake diaries. Appl Psycho Physiol Biofeed Back 2004;29:269-78

\section{Source of Support: Nil \\ Conflict of Interest: None Declared}

How to cite this URL: Kshama Kulkarni et al: An Overview on Yoga alongside Its Benefits in Menarche and Menopause. International Ayurvedic Medical Journal \{online\} 2021 \{cited September 2021\} Available from: http://www.iamj.in/posts/images/upload/2225_2231.pdf 